\title{
Convergencia arte-ciencia: Comentario sobre la obra de norberto Garcia Cairasco
}

\author{
Jairo A. Palta \\ University of Western Australia, Perth, Australia.
}

Con mucha frecuencia se ha considerado al arte y la ciencia como polos opuestos del conocimiento. Posiblemente esta apreciación tenga su origen en el hecho de que, en nuestra época de colegiales, se nos enseñó a mirarlos como entidades separadas. Este paradigma nos marcó hasta tal punto que, en el momento de seleccionar una carrera, hicimos que nuestra elección apuntara a uno solo de los dos -arte o ciencia- y, como resultado, "quedamos anclados" a un solo lado del cerco.

Si nos ubicamos en el lado de la ciencia, podemos afirmar que de ella aprendimos los métodos racionales que nos permitieron probar hipótesis, analizar e interpretar datos y llegar a conclusiones válidas, pero probablemente ignoramos que del arte también hubiésemos podido aprender a hacer cosas tan importantes como desarrollar argumentos, entender procesos, persuadir a los responsables de las políticas de investigación y, ¿por qué no decirlo? transformar las mentes de una humanidad heterogénea y diversa.

A medida que avanza el siglo XXI, hemos ido comprendiendo que esta manera de separar el arte y la ciencia no ha contribuido a la formación integral de profesionales, teniendo en cuenta que éstos deben enfrentar numerosos retos y desafíos, como por ejemplo, desplazarse entre diferentes lugares de trabajo, a menudo inestables, variados y repletos de información.

La convergencia entre el arte y la ciencia, vista como el punto en el que estas dos entidades confluyen, parece ser la manera más adecuada de conectarlas, en lugar de forzar la mezcla entre las dos. Esta confluencia nos lleva a considerar que el artista sea un científico y que a su vez, el científico sea un artista. Y este es exactamente lo que Norberto Garcia Cairasco representa.

La obra del Profesor García Cairasco revela una abstracción de la vida y de la mente humana, que puede ser de inmediato reconocida. Lo conozco desde hace 45 años, y puedo con certeza describirlo, no solo como constructor e inventor, sino también como investigador, soñador y pensador. Su obra representa la maravilla de la curiosidad y la complejidad de lo desconocido. A este respecto, traigo a colación lo que Albert Einstein dijo hace más de 60 años: "La cosa más bella que podemos experimentar es lo misterioso. Es la fuente de todo arte verdadero y de toda ciencia".

Así, es entonces en lo desconocido, en lo misterioso, donde el arte y la ciencia convergen. En su calidad de neurocientífico e investigador, Norberto Garcia Cairasco ha desarrollado nuevos conceptos de la función cerebral y los ha convertido en arte. Tomando imágenes estructurales de las células cerebrales, llamadas neuronas, las ha utilizado como materia prima para su trabajo artístico. Las neuronas son células altamente especializadas, con una estructura y una función bastante complejas y con un alto grado de plasticidad. Ciertamente, estas dos características son las que determinan que la investigación científica y la obra artística del Profesor Garcia Cairasco sean únicas.

En su obra, también hace presencia el sistema radicular o raíces de las plantas. Estas, al igual que las neuronas, son estructuras que se caracterizan por tener una arquitectura compleja y misteriosa y una función con elevada plasticidad. El sistema de raíces ha sido considerado como la mitad desconocida de las plantas y se ha predicho que ellas 
serán la base de una segunda revolución verde, la cual tendrá la virtud de mejorar el rendimiento de los cultivos en suelos poco fértiles y hostiles de los países del tercer mundo.

Algunas de las obras del Profesor Garcia Cairasco combinan -en forma por demás atractivaneuronas y raíces vegetales, de un modo que revela su plasticidad, es decir, su capacidad de cambiar a lo largo de la vida. Tanto el cerebro humano como el sistema radicular de las plantas poseen una increíble capacidad de reorganizarse en respuesta a las modificaciones del entorno: el cerebro humano, formando nuevas conexiones entre neuronas, y el sistema radicular, formando raíces fibrosas y adventicias para explorar el suelo. Así, el cerebro promedio de una persona tiene alrededor de $80 \mathrm{bi}-$ llones de neuronas, todas ellas emitiendo señales eléctricas o químicas dentro de redes intrincadas, pero coordinadas de tal manera que el resultado es una sinfonía capaz de crear la experiencia humana. Por otra parte, en una planta de centeno aparecen cada día 115 raíces y 119 millones de pelos absorbentes. Esto hace que la longitud total de las raíces que aparecen diariamente sea de $5 \mathrm{~km}$ (o 3 millas) y la de los pelos absorbentes, de $80 \mathrm{~km}$ (o 50 millas), lo que les permite conquistar y explorar nuevas zonas de suelo. La combinación feliz de neuronas y raíces de plantas, ideada por Norberto Garcia Cairasco no solo nos ilustra acerca de dos de las estructuras más complejas y repetitivas de la naturaleza, también representa dos inteligencias: la humana y la vegetal. Aunque las plantas son en general inmóviles y carecen de las actividades más conspicuas del cerebro animal, muestran ciertos atributos de comportamiento inteligente. Por ejemplo, los ápices de la raíz en el polo anterior del cuerpo de la planta tienen características que permiten proponer que, especialmente en sus zonas de transición, actúan como centros de comando semejantes a un cerebro. Los tejidos vasculares corresponden en realidad a vías de actividad nerviosa de la planta, que permiten un rápido intercambio de información entre las raíces y la parte aérea.

La interpretación real de la combinación entre neuronas y raíces vegetales en la obra de Norberto Garcia Cairasco es quizá más sencilla que la que acabo de esbozar, si aceptamos que, como artista y científico, él es el ejemplo de un ser humano excepcional que busca articular lo intangible con lo tangible y, al mismo tiempo, aumentar el conocimiento sobre órganos vitales.

$\mathrm{Su}$ obra constituye un valioso elemento inspirador para una nueva generación de científicos y, en general, para todo aquel que retenga la capacidad de asombrarse ante la absoluta maravilla de la complejidad y la plasticidad de las neuronas y de las raíces de las plantas. 